\title{
GENETIC ASPECTS OF IDIOPATHIC ESCOLIOSIS - A LITERATURE REVIEW
}

\author{
ASPECTOS GENÉTICOS DA ESCOLIOSE IDIOPÁTICA - UMA REVISÃO DE LITERATURA \\ ASPECTOS GENÉTICOS DE LA ESCOLIOSIS IDIOPÁTICA - UNA REVISIÓN DE \\ LA LITERATURA
}

Ricardo Vielra Teles Filho, ${ }^{1}$ Guilherme De Matos Abe, ${ }^{1}$ Nilo Carrijo Melo, ${ }^{2}$ Marcelo Fouad Rabahi, ${ }^{1}$ Murilo Tavares Daher ${ }^{1,2}$

1. Universidade Federal de Goiás, Faculdade de Medicina - DOT/FM/UFG, Goiânia, GO, Brazil.

2. Centro de Reabilitação e Readaptação Dr Henrique Santillo - CRER, Goiânia, Goiás, Brazil.

\begin{abstract}
The idiopathic scoliosis (IS) is the most common form of spinal deformity. The pathogenesis of IS is still poorly understood. Several studies show evidence that the genetic component is determinant to the development of IS. In this setting, a crescent focus has been placed on the identification of genes, associated genetic polymorphisms, and multiple susceptibility loci. This review highlights the genes and genetic polymorphisms currently studied, identified as influential in the genesis of IS, such as MMP-3, IL-6, type I collagen, and vitamin $\mathrm{D}$ and estrogen receptors. We concluded that IS remains a complex disease with a polygenic background and that genetic polymorphisms are intrinsically related to this condition. Level of evidence III; Narrative Review.
\end{abstract}

Keywords: Adolescent; Scoliosis; Spine; Genetics; Polymorphism, Genetic.

\section{RESUMO}

A escoliose idiopática (El) é a forma mais comum de deformidade da coluna vertebral. Porém, a patogênese ainda permanece mal compreendida. Diversos estudos apresentam evidências que o componente genético no desenvolvimento da El é determinante. Nesse sentido, um foco crescente foi colocado na identificação de genes, polimorfismos genéticos associados e múltiplos loci de susceptibilidade. A presente revisão destaca os genes e polimorfismos genéticos atualmente estudados, indicados como tendo influência na gênese da El, como os genes MMP-3, IL-6, do colágeno tipo 1, de receptores de vitamina D e de estrógenos. Conclui-se que a El permanece uma doença complexa, com antecedentes poligênicos, e que os polimorfismos genéticos estão intrinsecamente relacionados à esta condição. Nível de evidência III; Revisão Narrativa.

Descritores: Adolescente; Escoliose; Coluna Vertebral; Genética; Polimorfismo Genético.

\section{RESUMEN}

La escoliosis idiopática (EI) es la forma más común de deformidad de la columna vertebral. La patogénesis de la El sigue siendo poco conocida. Varios estudios presentan evidencias de que el componente genético en el desarrollo de la El es determinante. En ese sentido, existe un creciente enfoque en la identificación de genes, polimorfismos genéticos asociados y loci de susceptibilidad múltiples. La presente revisión destaca los genes y polimorfismos genéticos actualmente estudiados, identificados como influyentes en la génesis de la El, como los genes MMP-3, IL-6, colágeno tipo 1 y receptores de vitamina D y de estrógeno. Se concluye que la El sigue siendo una enfermedad compleja con antecedentes poligénicos y que los polimorfismos genéticos están intrínsecamente relacionados con esta condición. Nivel de evidencia III; Revisión Narrativa.

Descriptores: Adolescente; Escoliosis; Columna Vertebral; Genética; Polimorfismo Genético.

\section{INTRODUCTION}

Idiopathic scoliosis (IS) is a three-dimensional spinal deformity. The Scoliosis Research Society define it clinically as spinal curvature with angulation greater than $10^{\circ}$ in the coronal plane..$^{1,2}$ It is the most common form of spinal deformity with a prevalence of approximately $2-3 \%, 10 \%$ of which will progress over time. ${ }^{3}$ A young age, a pattern of thoracic curvature, and skeletal immaturity increase the probability of progression, ${ }^{4}$ leading to changes in adulthood, such as cosmetic deformity, pain, and even limitation of pulmonary function. 5,6

Four clinical subgroups are defined by age: infantile (up to 3 years of age), juvenile (from 4 to 10 years of age), adolescent (from 10 to 18 years of age), and adult (after 18 years of age). Adolescent IS is the most common and affects approximately $4 \%$ of the population, predominantly girls, with a gender ratio close to $8: 1 .{ }^{7}$ Most cases are diagnosed between 12 and 15 years of age and one out of every six will have a progressive curve that requires active treatment. ${ }^{8}$

The etiology and pathogenesis of IS are poorly understood, largely due to the heterogeneity of related factors. ${ }^{9}$ Some of the suggested etiological factors are growth pattern deviation, neuromuscular or connective tissue changes, asymmetric growth of the limbs and trunk, changes in the sagittal plane of the spine, environmental factors, and genetic influence. ${ }^{10,11}$ Studies about the familial aggregation of IS and concordance in monozygotic twins provided the first evidence of a possible primary genetic cause of the disease. ${ }^{12,13}$ Family-based genetic linkage studies have identified multiple loci of susceptibility. ${ }^{14,15}$ Loci have been identified that implicate possible

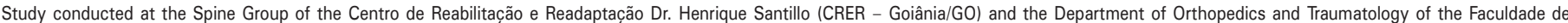
Medicina da Universidade Federal de Goiás - DOT/FM/UFG, Goiânia, Goiás, GO, Brazil.

Correspondence: Rua 70, 351, apto 302, Jardim Goiás, Goiânia, GO, Brasil. 74810-350. murilodaher@uol.com.br 
biological processes related to the pathogenesis of IS, such as axial modeling, cartilage formation, and growth asymmetries. ${ }^{7}$

New information has revealed that the genetic component is a determinant in the development of IS and that genetic polymorphisms are intrinsically related to this condition. ${ }^{16}$ In the last two decades, analyses of genomic association in the genomes of individuals with IS have been conducted in an attempt to identify genetic variations that predict the disease. ${ }^{14}$ Therefore, the objective of this study is to gather the main polymorphisms currently being studied through a narrative review of the literature, providing updates that can help elucidate the etiopathogenesis of IS and foster new diagnostic and therapeutic approaches to IS.

\section{METHODS}

The bibliographical research was conducted using the Medline, Scielo and Web of Science databases and systematic reviews of the Cochrane Library. Articles selected from three types of studies were included: familial aggregation studies with twins, case-control studies, and meta-analyses. Because the objective of our study was to retrieve advances in studies establishing causal relationships between IS and genetic factors, we did not determine a minimum publication date for article selection. We used "Adolescent", "Deformity", "Scoliosis", "Spine", "Genetics", and "Polymorphism" as descriptors. Only works that addressed the correlation of genes, genetic variations, or genetic polymorphism related to structure, or deformities related to the genesis of IS, were included. Repeated articles, dissertations, theses, validation articles, and those that did not make the full text available were excluded. Works that described structural spinal changes directly related to candidate genetic mechanisms were also included. We also checked their respective references in search of additional articles. This study is a literature review not involving patients so it was not submitted to the Institutional Review Board for approval.

\section{RESULTS}

We found 27 works that met the evaluation criteria, including 8 relevant studies with twins and familial aggregation; 15 case-control studies addressing the most relevant currently associated genes - MMP-3, IL-6, the collagen and vitamin D receptor genes, and estrogen; and finally, 4 meta-analyses of the same.

\section{DISCUSSION}

Population-based association studies and genetic sequencing approaches have identified numerous loci associated with the disease, however, a lack of appropriate animal models has made understanding its biological origins difficult. ${ }^{17}$ Most of the genetic studies for adolescent IS prior to 2010 are based on candidate genes selected based on hypotheses generated from clinical observations. Most of these genes are unconfirmed or have widely varying published results, depending on the structuring of the study and/or populations tested. ${ }^{14}$

Initially, studies with twins were conducted that showed the preponderance of genetic factors in relation to the environmental factors of deformity genesis. Subsequently, case-control studies tried to identify the genes and polymorphisms involved in the genesis and progression of the disease.

\section{Studies with twins and familial aggregation}

Studies with twins and familial aggregation are usually the starting point for in-depth investigations of the genetic influence on a specific disease, since they are capable of identifying similarities between individuals with close genetic profiles (Table 1).

Wynne-Davies analyzed familial incidence of IS, reporting that $6.94 \%$ of first-degree relatives, $3.69 \%$ of second-degree relatives, and $1.55 \%$ of third-degree relatives were affected..$^{18}$ In 1970, Cowell evaluated a database with 36 million names and constructed multi-generational family lineages, demonstrating that $97 \%$ of the patients with adolescent IS were related to other families with adolescent IS. ${ }^{19}$ Two years later, the same author evaluated 110 families and reported that $80 \%$ of the patients with adolescent IS had other affected family members. ${ }^{20}$
In 1976, Kling analyzed a series of systematic reviews and reported an IS concordance rate of $73 \%$ in 37 pairs of monozygotic twins and $36 \%$ in 31 pairs of dizygotic twins. ${ }^{21}$

Czeizel and Riseborough also observed a higher occurrence of adolescent IS in first-degree relatives than in the general population. 22,23 Data about IS in twins in the Swedish population in 2012 supported the claim that $38 \%$ of the cases that developed IS had a familial genetic component. ${ }^{24}$

In Brazil, Wajchenberg, analyzed the genealogy of 100 Brazilian families that had at least one member with adolescent IS with a curve greater than or equal to $20^{\circ}$ and reported that $33 \%$ had some family member with the same disease, 5.21\% being first-degree relatives, $4.54 \%$ second-degree relatives, and $8.97 \%$ third-degree relatives. ${ }^{25}$

\section{Case-control studies - evaluations of polymorphisms}

From the studies that confirmed the preponderance of genetic factors in the genesis of IS, case-control studies became necessary to analyze the possible associated polymorphisms. These polymorphisms were based on clinical observation of the patients and of the possible related structures. In 2010, K. Ward identified more than 300 single nucleotide polymorphisms (SNPs) that are related statistically to the progression of adolescent IS curves, concluding from the analysis of case-control studies that adolescent IS is a complex autosomal and polygenic disease with dominant, recessive, and codominant inheritance patterns. ${ }^{26}$

In this review, we will cite the most-studied genetic polymorphisms. There are a large number of polymorphisms being studied, for which information is scarce of for which there are no systematized studies. We will review the type I collagen gene associated with the structuring of the intervertebral disc, the matrix metalloproteinase-3 gene (MMP-3) that produces enzymes capable of breaking down the disc, and genes related to bone structure - the vitamin D and estrogen receptor genes. (Table 2)

Table 1. List of studies with twins and familial aggregation.

\begin{tabular}{c|c}
\hline Study & Country \\
\hline Wynne-Davies, 1968 & USA \\
\hline Cowell et al., 1970 & USA \\
\hline Cowell et al., 1972 & USA \\
\hline Riseborough et al., 1973 & USA \\
\hline Kesling et al., 1997 & USA \\
\hline Czeizel et al., 1978 & Hungary \\
\hline Wajchenberg et al., 2005 & Brazil \\
\hline Grauers et al., 2012 & Sweden \\
\hline
\end{tabular}

Table 2. List of candidate genes and published works.

\begin{tabular}{|c|c|c|}
\hline Candidate gene & Work & Country \\
\hline \multirow{6}{*}{ MMP-3 } & Aulisa et al., $2007^{29}$ & Italy \\
\hline & Liu et al., $2010^{33}$ & China \\
\hline & Mórocz et al., $2011^{30}$ & Hungary \\
\hline & Zhao et al., $2016^{31}$ & China \\
\hline & Nikolova et al., $2016^{34}$ & Bulgaria \\
\hline & Sui et al., $2017^{32}$ & China \\
\hline \multirow{5}{*}{ IL-6 } & Aulisa et al., $2007^{29}$ & Italy \\
\hline & Liu et al., $2010^{33}$ & China \\
\hline & Mórocz et al., $2011^{30}$ & Hungary \\
\hline & Nikolova et al., $2015^{35}$ & Bulgaria \\
\hline & Nikolova et al., $2016^{34}$ & Bulgaria \\
\hline \multirow{2}{*}{ Collagen I } & Toktas et al., $2015^{39}$ & Turkey \\
\hline & Haller et al., $2016^{40}$ & USA \\
\hline \multirow{3}{*}{ VDR } & Suh et al., $2010^{41}$ & South Korea \\
\hline & Toktas et al., $2015^{39}$ & Turkey \\
\hline & Yin et al., $2017^{42}$ & China \\
\hline \multirow{4}{*}{ Estrogen receptor } & Wu et al., $2006^{43}$ & China \\
\hline & Janusz et al., $2014^{44}$ & Poland \\
\hline & Nikolova et al., $2015^{35}$ & Bulgaria \\
\hline & Skibinska et al., $2016^{45}$ & Poland \\
\hline
\end{tabular}




\section{MMP-3}

Matrix metalloproteinases (MPPs), such as MMP-3, are potent proteoglycan-degrading enzymes that play an important role in intervertebral disc degeneration (IVDD) ${ }^{27}$ Many studies point to a correlation between the degree of histological degeneration and MMP-3 that has increased significantly in the nuclei pulposi (NP), altering the constitution of their matrix. This change has been associated with the development of conditions that favor the development of IS. ${ }^{28-30}$

Genetic polymorphism in the MMP-3 promoter gene has been reported to be involved in MMP-e expression. Gene regulation and certain alleles, such as $5 \mathrm{~A}$, have been indicated as risk factors for the acceleration of degenerative lumbar disc changes. ${ }^{12,31}$ Thus, the relationship between MMP-3 polymorphisms and IS has been one of the most investigated associations and the one presented in the greater number of studies. However, in spite of those studies reporting this possible action, there is no consensus about the already proven relationship between MMP-3 and the onset or progression of IS. ${ }^{32,33}$

\section{IL-6}

Several inflammation mediators, including interleukin 1 (IL-1) and interleukin 6 (IL-6) have been implicated in IS etiopathogenesis. ${ }^{34,35}$ IL-6 is an important inflammation mediator and is involved in lumbar disc herniation. Despite this, the exact role of IL-6 in IS has not been fully elucidated. ${ }^{18}$ It has been shown that the NP of scoliotic discs respond to exogenous pro-inflammatory stimuli by secreting increased amounts of IL-6 and other pro-inflammatory cytokines. ${ }^{29,31,34}$

Studies documenting single nucleotide polymorphisms (SNP) in the gene of IL-6 have been widely performed, aimed at documenting what the real role of this polymorphism is in inflammatory imbalance and in its influence on the matrix changes in IVDD. ${ }^{30,32,36}$ The hypothesis is that this polymorphism leads to imbalance of the pro-inflammatory cytokines and, thus, accelerates inflammation, because the expression of IL-6 RNA-m is in fact highly correlated with the levels of IL-1 beta RNA-m, tumor necrosis factor alpha (TNF- $\alpha$ ), IL-8, MMP-3, MMP-9, and MMP-12. ${ }^{37,38}$

\section{Type I Collagen}

Alterations in the codification genes of type I collagen would lead to the structural imbalance of IVDD, and in turn it would morphologically alter the distribution of loads, leading to abnormal curvatures. ${ }^{37,39}$ Studies have been developed with the intention of defining the degree of influence of collagen alterations, especially that of type I in the determination of the curvatures present in IS, particularly in the annulus fibrosis (AF) where collagen I creates a network of fibers that function to retain the NP, which in turn has reticulated collagen IX fibers and collagen II fibers to provide stability. ${ }^{40}$

\section{Vitamin D receptor}

1.25-dihydroxyvitamin D3 plays a central role in skeletal metabolism, binding to its nuclear steroid receptor, the vitamin $D$ receptor (VDR). About $40 \%$ of skeletal mass is acquired during puberty and vitamin D performs an important role in this gain during adolescence. In addition, it has been reported that girls with hypovitaminosis $D$ run the risk of not achieving the maximum bone mass desired for that age, which suggests that the genes of any component of the vitamin $D$ endocrine system is a candidate locus as gene influencing vertebral formation. ${ }^{41}$

Researchers have analyzed the association between polymorphisms of the VDR and DMO genes and their influence on abnormal curves, since modified receptors would alter the physiological metabolism of vitamin D. ${ }^{42}$ However, studies to demonstrate the relationship between bone mass in girls with IS and polymorphism of VDR are still lacking. What we have in the literature is the female predominance as a risk factor for the development El as already presented. ${ }^{43}$

\section{Estrogen receptor}

One of the theories about the etiology of IS is associated with the potential influence of estrogens and estrogen receptors in the formation of IVDD, of vertebral structures, and in the cell function of the paraspinal musculature. Estrogens affect muscle tissue function in terms of adaptation to angiogenesis and myogenesis resistance training. ${ }^{44}$

Furthermore, the estrogens repress bone remodeling and the balance of control between bone formation and reabsorption. ${ }^{45}$ Expression of the estrogen receptor was detected in human osteoblasts and osteoclasts and mutation in the gene codifier of the estrogen receptor caused bone loss and delay in skeletal growth in human beings. The association between polymorphisms of the estrogen receptor gene and bone density was reported by different investigators, but this relationship is not firmly established. ${ }^{46,47}$

\section{Systematic reviews and meta-analyses}

Through the systematic review, we discovered that IS has multifactorial hereditary characteristics and multiple genes are affected by the development of the disease. Genes discovered as being linked to IS include SNTG1 at 8q11.22, ESR1 at 6q25.1, and CHD7 at 8q12.1. ${ }^{3}$

Out of 50 studies, KF Gorman et al. identified 34 studies of candidate genes (6 linkages, 28 associations) and 16 complete genome studies (14 linkages based on lineage, 2 studies of complete genome association). The findings involved genes related to the structure of connective tissue, such as type I collagen, the formation/metabolism of MMP-3, inflammation signalization paths such as IL-6, and secondary paths, such as melatonin and axonal guidance paths. It should be noted that the variability among the results suggests ethnic and/or genetic heterogeneity. ${ }^{4}$

It was concluded that the main difficulty in IS research is phenotypical and genetic heterogeneity. Weak studies were over-represented in the genetics research. The use of biological models and restrictive clinical definitions may help to separate variations and increase the potency of studies to detect or confirm an effect. ${ }^{14}$

Using meta-analysis aimed at detecting whether the main genetic polymorphisms, those of MMP-3 and IL-6, are correlated with adolescent IS, CK Kepler concluded that, overall, there is no significant association between IL-6 genetic polymorphism and the risk of adolescent IS. A significant association was observed in the homozygotic model of genetic MMP-3 polymorphism. When stratified into Caucasian and Asiatic populations, a positive association was observed in the Caucasian population, while there was no significant association observed in the Asiatic population. This study concluded that certain genotypes of genetic MMP-3 polymorphism were associated with adolescent IS, especially in the Caucasian population. However, no significant association was detected between IL-6 genetic polymorphism and adolescent IS. ${ }^{31}$ Meta-analyses of the involvement of VDR and estrogen receptors lack sufficient statistical data to indicate any correlation.

Few studies to date have applied complete genome association testing in populations of individuals with IS. This is mainly related to the high cost of this type of testing in large populations, which is believed to be necessary for the detection of significant results that could be applied to the general population. This reflects the real complexity of IS. Although the disease aggregates within families, it does not segregate clearly like a "Mendelian" disease. ${ }^{48}$ Genetic and environmental interactions may be essential to the expression of IS. Individual alleles may vary from one affected subject to another and they may not be either necessary or sufficient to be caused by nature. Knowledge of the causal mechanisms of a complex genetic disease like IS is an essential step towards the development of efforts for focal/practical application of the Human Genome Project to clinical medicine. ${ }^{49}$

\section{CONCLUSION}

It is known that IS is a polygenic disease influenced by various genes that codify essential spinal support proteins. It is not possible to determine precisely all the genes involved, but certain polymorphisms are already being related, such as those of the metalloproteinases, collagen codifiers, and estrogen and 
vitamin D receptors. In this way, the polymorphism of these genes and their expression in tissues still require further investigation in order to propose more assertive therapeutic targets that corroborate with the non-progression of the disease. The identification of diagnostically and prognostically valuable molecular markers can be useful in early detection in children at risk for developing IS and for prognosis, with more certain means for predicting the risk of progression, for avoiding follow-ups, potentially unnecessary radiographs and treatments, and for the application of more effective treatment.

All authors declare no potential conflict of interest related to this article.

CONTRIBUTION OF THE AUTHORS: Each author made significant individual contributions to this manuscript. RVTF (0000-0003-4822-1526) and GMA $(0000-0002-2446-3750)^{*}$ conducted the literature review and wrote the manuscript. NCM (0000-0003-3879-6991)* and MFR (0000-0002-4050-5906)* reviewed the manuscript. MTD (0000-0001-9589-5596)* developed the study concept, was the advisor for the literature review, and performed the final review of the manuscript. *ORCID (Open Researcher and Contributor ID).

\section{REFERENCES}

1. Hresko MT. Idiopathic Scoliosis in Adolescents. N Engl J Med. 2013;368(9):834-41

2. Zhang J, Lou E, Le LH, Hill DL, Raso JV, Wang Y. Automatic Cobb Measurement of Scoliosis Based on Fuzzy Hough Transform with Vertebral Shape Prior. J Digit Imaging. 2009;22(5):463-72

3. Yaman O, Dalbayrak S. Idiopathic scoliosis. Turk Neurosurg. 2014;24(5):646-57

4. Wong H-K, Tan K-J. The natural history of adolescent idiopathic scoliosis. Indian J Orthop. 2010:44(1):9-13

5. Vavruch L, Forsberg D, Dahlström N, Tropp H. Vertebral Axial Asymmetry in Adolescent Idiopathic Scoliosis. Spine Deform. 2017;6(2):112-20.

6. Weinstein SL, Dolan LA, Spratt KF, Peterson KK, Spoonamore MJ, Ponseti IV. Health and Function of Patients With Untreated Idiopathic Scoliosis. JAMA. 2003;289(5):559-67.

7. Boswell CW, Ciruna B. Understanding Idiopathic Scoliosis: A New Zebrafish School of Thought. Trends Genet. 2017:33(3):183-96.

8. Julien C, Gorman KF, Akoume M, Moreau A. Towards a comprehensive diagnostic assay for scoliosis. Per Med. 2013;10(1):97-103

9. Negrini S, Aulisa A, Aulisa L, Circo A, De Mauroy JDJ, Durmala J, et al. 2011 SOSORT guidelines: Orthopaedic and Rehabilitation Treatment of Idiopathic Scoliosis During Growth. Scoliosis. 2012;7:3

10. Schlösser TPC, Van Der Heijden GJMG, Versteeg AL, Castelein RM. How "idiopathic" is adolescent idiopathic scoliosis? A systematic review on associated abnormalities. PLoS One. 2014;9(5):e97461.

11. Cheng JC, Castelein RM, Chu WC, Danielsson AJ, Dobbs MB, Grivas TB, et al. Adolescent idiopathic scoliosis. Nat Rev Dis Prim. 2015;1:15030.

12. Grauers A, Einarsdottir E, Gerdhem P. Genetics and pathogenesis of idiopathic scoliosis. Scoliosis Spinal Disord. 2016;11:45.

13. Olbertz CMCA, De Gauzy JS, De Albuquerque PCVC, Accadbled F, De Albuquerque PEMC, Aguiar JDLA. Concordance for curve type in idiopathic scoliosis among family members. Acta Ortop Bras. 2017;25(3):90-4.

14. Gorman KF, Julien C, Moreau A. The genetic epidemiology of idiopathic scoliosis. Eur Spine J. 2012:21(10):1905-19

15. Ogilvie JW. Update on prognostic genetic testing in adolescent idiopathic scoliosis (AIS). J Pediatr Orthop. 2011:31(1 Suppl):S46-8.

16. Ikegawa S. Genomic study of adolescent idiopathic scoliosis in Japan. Scoliosis Spinal Disord. 2016;11:5.

17. Yeramaneni S, Robinson C, Hostin R. Impact of spine surgery complications on costs associated with management of adult spinal deformity. Curr Rev Musculoskelet Med. 2016;9(3):327-32

18. Wynne-Davies R. Familial (idiopathic) scoliosis. A family survey. J Bone Joint Surg Br. 1968:50(1):24-30.

19. Cowell HR. Genetic aspects of orthopedic diseases.Clin Orthop Relat Res. 1975;(107):36-47

20. Cowell HR, Hall JN, McEwen GD. Genetic Aspects of Idiopathic Scoliosis: A Nicholas Andry Award Essay. Clin Orthop Relat Res. 1972:86:121-31.

21. Kling TF. Point of View: Scoliosis in Twins: A Meta-analysis of the Literature and Report of Six Cases. Spine (Phila Pa 1976). 1997;22(17):2009-14

22. Czeizel A, Bellyei A, Barta O, Magda T, Molnár L. Genetics of adolescent idiopathic scoliosis J Med Genet. 1978:15(6):424-7.

23. Riseborough EJ, Wynne-Davies R. A Genetic Survey of Idiopathic Scoliosis in Boston, Massachusetts. J Bone Jt Surg Br. 1973;55(5):974-82.

24. Grauers A. Rahman I, Gerdhem P. Heritability of scoliosis. Eur Spine J. 2012:21(6):1069-74.

25. Wajchenberg M, Martins DE, Puertas EB. Aspectos genéticos da escoliose idiopática do adolescente. Coluna/ Columna. 2012;11(3):234-6.

26. Ward K, Ogilvie J, Argyle V, Nelson L, Meade M, Braun J, et al. Polygenic inheritance of adolescent idiopathic scoliosis: A study of extended families in Utah. Am J Med Genet Part A. 2010;152A(5):1178-88.

27. Shu CC, Melrose J. The adolescent idiopathic scoliotic IVD displays advanced aggrecanolysis and a glycosaminoglycan composition similar to that of aged human and ovine IVDs. Eur Spine J. 2018;27(9):2102-13.

28. Eser B, Eser O, Yuksel Y, Aksit H, Karavelioglu E, Tosun M, et al. Effects of MMP-1 and MMP-3 gene polymorphisms on gene expression and protein level in lumbar disc herniation. Genet Mol Res. 2016;15(3):1-10.

29. Aulisa L, Papaleo P, Pola E, Angelini F, Aulisa AG, Tamburrelli FC, et al. Association between
IL-6 and MMP-3 gene polymorphisms and adolescent idiopathic scoliosis: a case-control study. Spine (Phila Pa 1976). 2007:32(24):2700-2

30. Mórocz M, Czibula Á, Grózer ZB, Szécsényi A, Álmos PZ, Raskó I, et al. Association Study of BMP4, IL6, Leptin, MMP3, and MTNR1B Gene Promoter Polymorphisms and Adolescent Idiopathic Scoliosis. Spine (Phila Pa 1976). 2011:36(2):E123-30.

31. Zhao J, Yang M, Li M. Association of IL-6 and MMP-3 gene polymorphisms with susceptibility to adolescent idiopathic scoliosis: a meta-analysis. J Genet. 2016;95(3):573-9.

32. Sui W, Yang J, Huang Z, Wang Q, Fan H, Deng Y. Polymorphisms in promoter regions of MMP-3 and IL-6 genes are not associated to adolescent idiopathic scoliosis (AIS) gender bias. J Back Musculoskelet Rehabil. 2017;30(3):559-63.

33. Liu Z, Tang NLS, Cao X-B, Liu W-J, Qiu X-S, Cheng JCY, et al. Lack of association between the promoter polymorphisms of MMP-3 and IL-6 genes and adolescent idiopathic scoliosis: a case-control study in a Chinese Han population. Spine (Phila Pa 1976). 2010:35(18):1701-5.

34. Nikolova ST, Yablanski VT, Vlaev EN, Stokov LD, Savov AS, Kremensky IM, et al. Association Between IL-6 and MMP3 Common Genetic Polymorphisms and Idiopathic Scoliosis in Bulgarian Patients. Spine (Phila Pa 1976). 2016;41(9):785-91.

35. Nikolova S, Dikova M, Dikov D, Djerov A, Dzhebir G, Atanasov V, et al. Role of the IL-6 gene in the etiopathogenesis of idiopathic scoliosis. Anal Cell Pathol. 2015;2015:5-9.

36. Wang S, Rui Y, Lu J, Wang C. Cell and molecular biology of intervertebral disc degeneration: Current understanding and implications for potential therapeutic strategies. Cell Prolif. 2014;47(5):381-90.

37. Kepler CK. Ponnappan RK. Tannoury CA, Risbud MV, Anderson DG. The molecular basis of intervertebral disc degeneration. Spine J. 2013;13(3):318-30.

38. Johnson ZI, Schoepflin ZR, Choi H, Shapiro IM, Risbud MV. Disc in flames: Roles of TNF- $\alpha$ and IL-1 $\beta$ in intervertebral disc degeneration. Eur Cells Mater. 2015;30:104-16

39. Toktas ZO, Ekși MS, Yılmaz B, Demir MK, Özgen S, Kılıc T, et al. Association of collagen I, IX and vitamin D receptor gene polymorphisms with radiological severity of intervertebral disc degeneration in Southern European Ancestor. Eur Spine J. 2015;24(11):2432-41.

40. Haller G, Alvarado D, Mccall K, Yang P, Cruchaga C, Harms M, et al. A polygenic burden of rare variants across extracellular matrix genes among individuals with adolescent idiopathic scoliosis. Hum Mol Genet. 2016;25(1):202-9.

41. Yin X, Wang $H$, Guo J, Zhang L, Zhang Y, Li L, et al. Association of vitamin D receptor Bsml rs1544410 and Apal rs7975232 polymorphisms with susceptibility to adolescent idiopathic scoliosis. Medicine (Baltimore). 2018;97(2):e9627.

42. Wang Y, Cui ZQ, Luo TB, Liu L. Correlations of VDR and VDBP genetic polymorphisms with susceptibility to adolescent idiopathic scoliosis and efficacy of brace treatment. Genomics. 2016;108(5-6):194-200.

43. Suh KT, Eun I-S, Lee JS. Polymorphism in vitamin D receptor is associated with bone minera density in patients with adolescent idiopathic scoliosis. Eur Spine J. 2010:19(9):1545-50.

44. Skibinska I, Tomaszewski M, Andrusiewicz M, Urbaniak P, Czarnecka-Klos R, Shadi $M$, et al. Expression of estrogen receptor coactivator proline-, glutamic acid- and leucine-rich protein 1 within paraspinal muscles in adolescents with idiopathic scoliosis. PLoS One. 2016;11(4):e0152286.

45. Zamecnik J, Krskova L, Hacek J, Stetkarova I, Krbec M. Etiopathogenesis of adolescent idiopathic scoliosis: Expression of melatonin receptors $1 \mathrm{~A} / 1 \mathrm{~B}$, calmodulin and estrogen receptor 2 in deep paravertebral muscles revisited. Mol Med Rep. 2016;14(6):5719-24

46. Wu J, Qiu Y, Zhang L, Sun Q, Qiu X, He Y. Association of Estrogen Receptor Gene Polymorphisms With Susceptibility to Adolescent Idiopathic Scoliosis. Spine (Phila Pa 1976). 2006;31(10):1131-6.

47. Janusz P, Kotwicka M, Andrusiewicz M, Czaprowski D, Czubak J, Kotwicki T. Estrogen receptors genes polymorphisms and age at menarche in idiopathic scoliosis. BMC Musculoskelet Disord. 2014:15:383.

48. Luk KDK, Lee CF, Cheung KMC, Cheng JCY, Ng BKW, Lam TP, et al. Clinical effectiveness of school screening for adolescent idiopathic scoliosis: a large population-based retrospective cohort study. Spine (Phila Pa 1976). 2010:35(17):1607-14.

49. Miller NH. Idiopathic scoliosis: Cracking the genetic code and what does it mean? J Pediatr Orthop. 2011;31(1 Suppl):49-52. 